\title{
MENGENAL PERILAKU KONSUMEN MELALUI PENELITIAN MOTIVASI*)
}

\author{
Albari \\ Fakultas Ekonomi \\ Universitas Islam Indonesia
}

\begin{abstract}
Abstrak
Dalam khasanah literatur tentang perilaku konsumen masih sulit ditemui bab yang membicarakan secara khusus tentang prosedur dan teknik penelitian yang bisa mengungkap motivasi konsumen untuk membeli suatu produk/merek tertentu. Untuk mengurangi kelemahan itu, tulisan ini mencoba memberi tambahan wacana penelitian motivasi konsumen dengan mengajukan alternatif pengukuran data yang disesuaikan dengan pendekatan teori motivasi yang digunakan.

Dibahas pula teknik analisis statistika untuk memanfaatkan data yang berhasil diperoleh serta implikasi hasilnya dalam pemasaran, sehingga dapat membantu dalam pengambilan kesimpulan penelitian.
\end{abstract}

Kata kunci: Perilaku konsumen, motivasi konsumen.

PENDAHULUAN

Ketika konsumen sangat menginginkan suatu produk/merek, tetapi mereka tidak bisa memperoleh pilihan penawaran pemenuhan yang cukup, maka pemasar dapat memperoleh pengertian mengenai perilaku konsumen itu dengan mudah. Namun seiring dengan berkembangnya perusahaan dan pasar muncul tingkat persaingan yang semakin lama semakin ketat serta resiko kegagalan usaha yang semakin besar pula. Dan pada saat ini pemasar memerlukan data (perilaku) konsumen yang akurat, sehingga perusahaaan dapat mempertahankan, dan bahkan mengembangkan keberadaanya di pasar.

Melalui penelitian, studi tentang konsumen dan perilakunya ini dapat dipahami. Meskipun hasil prediksi yang sempurna mungkin tidak akan diperoleh, namun usaha yang didesain dengan tepat akan dapat mengurangi risiko kegagalan pemasaran secara berarti, dibandingkan jika pengambilan keputusan manajerial tidak dilengkapi dengan data dari pendapat konsumen.

Dalam pembahasan tentang perilaku konsumen, terdapat banyak pengaruh yang mendasari seseorang dalam mengambil keputusan pembelian suatu produk/merek yang harus dipelajari oleh pemasar. Pada kebanyakan orang, perilaku pembelian konsumen seringkali diawali dan dipengaruhi oleh banyaknya rangsangan (stimuli) dari luar dirinya, baik

*) Jurnal Siasat Bisnis Edisi No. 7 Vol. 1, Th. 2002 
berupa rangsangan pemasaran maupun rangsangan dari lingkungannya yang lain. Rangsangan tersebut kemudian diproses (diolah) dalam diri, sesuai dengan karakteristik pribadinya, sebelum akhirnya diambil keputusan pembelian. Karakteristik pribadi konsumen yang dipergunakan untuk memproses rangsangan tersebut sangat komplek $^{1}$, dan salah satunya adalah motivasi konsumen untuk membeli.

Menurut Wells dan Prensky (1996), motivasi sebagai titik awal dari semua perilaku konsumen, yang merupakan proses dari seseorang untuk mewujudkan kebutuhannya serta memulai melakukan kegiatan untuk memperoleh kepuasan. Sedangkan Schiffman dan Kanuk (1994) menyatakan bahwa motivasi sebagai kekuatan dorongan dari dalam diri individu yang memaksa mereka untuk melakukan tindakan. Kekuatan dorongan tersebut dihasilkan dari suatu tekanan yang diakibatkan oleh belum atau tidak terpenuhinya kebutuhan, keinginan dan permintaan. Kemudian bersama-sama dengan proses kognitif (berfikir) dan pengetahuan yang sebelumnya didapat, maka dorongan akan menimbulkan perilaku untuk mencapai tujuan atau pemenuhan kebutuhan. Proses ini dapat ditunjukkan seperti pada Gambar 1.

Dengan demikian, jika seseorang mempunyai motivasi yang tinggi terhadap obyek tertentu, maka dia akan terdorong untuk berperilaku menguasai obyek tersebut. Sebaliknya jika motivasinya rendah, maka dia akan mencoba untuk menghindari obyek yang bersangkutan. Implikasinya dalam pemasaran adalah kemungkinan orang tersebut berminat untuk membeli produk/merek yang ditawarkan pemasar atau tidak.

\section{Gambar 1: Model Proses Motivasi (Schiffman dan Kanuk, 1994)}

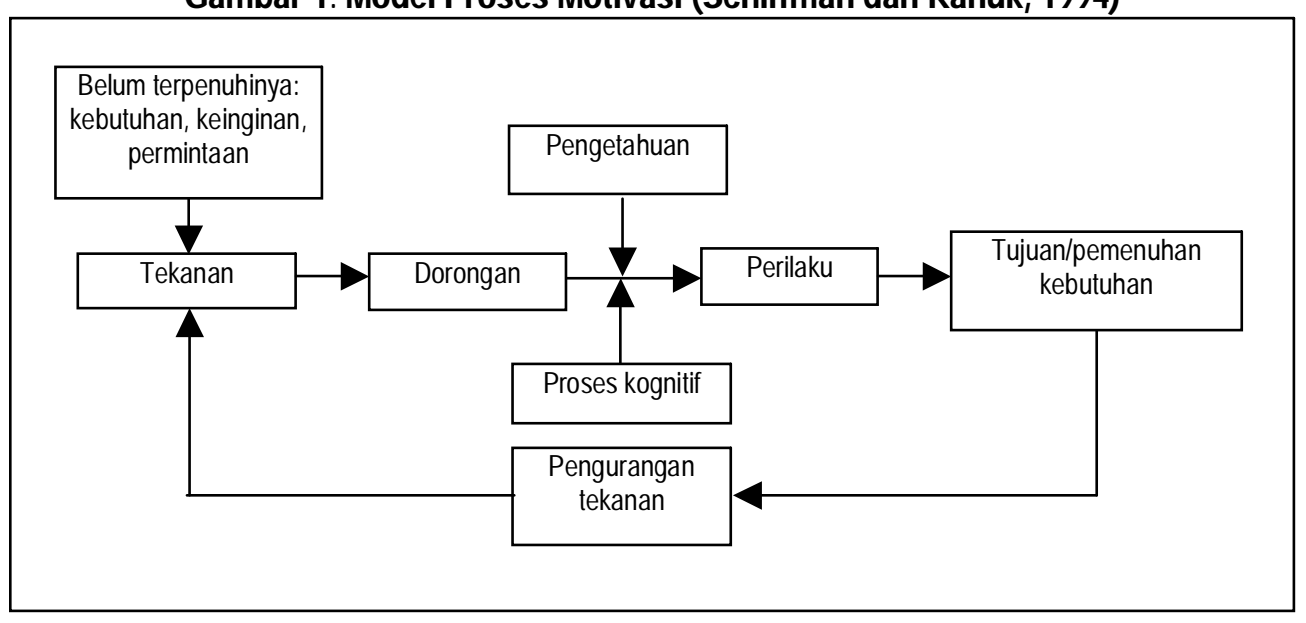

${ }^{1}$ Kotler (1994) menyebutnya kotak hitam pembeli. 
Menyadari pentingnya motivasi tersebut, maka tulisan ini mencoba memberi gambaran dalam melakukan penelitian tentang motivasi konsumen untuk membeli suatu produk/merek. Karena suatu penelitian tidak banyak mempunyai arti jika tanpa memberikan kontribusi atau perbaikan dalam kehidupan sehari-hari, maka tulisan ini akan dilengkapi pula dengan bahasan implikasi yang mungkin dapat diperoleh dalam kebijakan pemasaran.

\section{KONTEKSTUAL DAN KONDISIONAL}

Pada setiap kegiatan penelitian, seorang peneliti perlu mengemukakan secara jelas tentang pentingnya penelitian itu dilakukan dengan tema atau judul tertentu. Penjelasan itu memuat rincian alasan atau latar belakang yang komprehensif dan sesuai dengan konteks dan kondisi obyektif, seperti yang tersirat ditunjukkan dalam tema atau judul penelitian tersebut.

Konteks penelitian berhubungan dengan penekanan penelitian pada aspek tertentu yang dianggap penting untuk diteliti, sedangkan kondisi bersangkutan dengan fenomena yang terjadi dan berkaitan dengan realitas obyek yang diteliti [perusahaan, produk, merek]. Jika kontekstual merujuk pada teori yang dipakai dan mendasari tema pokok penelitian, maka kondisi dapat dicerminkan oleh variabel, atribut, atau sifat dari obyek itu. Untuk sampai pada tingkatan kondisional, maka variabel, atribut, atau sifat obyek harus sesuai dengan muatan teori yang dipilih dalam penelitian.

Demikian eratnya hubungan antara kontekstual dan kondisional penelitian ini, sehingga tidak boleh terjadi dalam suatu penelitian terdapat alasan atau latar belakang penelitian yang tidak menyentuh penjelasan tentang teori dan obyek penelitian. Dengan kata lain, peneliti perlu menjelaskan teori yang digunakan dalam penelitian - diantara berbagai teori yang mungkin ada, dan obyek yang dipilih sudah harus tertentu.

Sebagai ilustrasi, misalnya penelitian mengenai motivasi konsumen untuk membeli produk/merek X. Maka konteks penelitiannya adalah teori motivasi tertentu dengan segala aspek yang tersirat di dalamnya, sedangkan kondisi penelitiannya adalah harga, kualitas dan atribut yang lain dari produk/merek $X$, yang dapat mewakili penerapan aspek-aspek teori motivasi tadi secara obyektif.

Dalam perkembangannya terdapat beberapa teori motivasi yang dapat digunakan sebagai dasar penelitian. Masing-masing teori akan membawa implikasi yang berbeda dalam teknik pengukuran, analisis, dan implikasi pemasarannya. Namun secara sederhana, penelitian motivasi perlu bertolak pada teori tertentu dan berusaha mengungkap semua faktor atau kaadaan yang mendasari atau dorongan bawah sadar yang dapat berpengaruh pada perilaku konsumen, seperti atribut penting dari produk 
atau jasa pada target konsumen yang dituju (Thomas, 1998). Di antara teori motivasi yang ada dan dapat dijadikan acuan penelitian konsumen yaitu: teori kebutuhan Maslow dan teori psikoanalitik kepribadian Freud.

Secara konvensional pembahasan tentang motivasi banyak didasarkan pada teori hirarki kebutuhan manusia dari Maslow. Teori ini berusaha menjelaskan motivasi manusia melalui pemenuhan kebutuhan biologi dan psikologi manusia, berupa kebutuhan fisiologis, keamanan, sosial, penghargaan diri, dan aktualisasi diri (Solomon, 1999). Dalam konteks pemasaran, kebutuhan fisiologis dapat berupa cerminan kemampuan konsumen untuk membeli dengan harga atau biaya tertentu, kebutuhan kaamanan berupa tingkat kaamanan dalam menggunakan produk/merek (misalnya garansi, pelayanan purna jual, atau tersedianya suku cadang), kebutuhan sosial dicerminkan oleh kegunaan produk dalam hubungannya dengan masyarakat, kebutuhan penghargaan diri dapat berupa bagian produk/merek yang bisa mengangkat citra diri konsumen, dan kebutuhan aktualisasi diri dapat ditunjukkan oleh kegunaan utama produk/merek yang dapat menunjang pencapaian potensi diri konsumen.

Dapat terpenuhinya suatu kebutuhan akan menimbulkan motivasi untuk memenuhi kebutuhan yang lain. Pemenuhan kebutuhan tersebut tersusun dalam sebuah jenjang dari tingkatan yang paling mendesak sampai dengan yang kurang mendesak, meskipun bukan berarti harus dimulai dari kebutuhan fisiologis ke atas sampai dengan kebutuhan aktualisasi diri. Tetapi selalu ada kemungkinan pengecualian dari kecenderungan tersebut. Seseorang kadang-kadang justru lebih termotivasi untuk memenuhi kebutuhan aktualisasi karena dia ingin memacu pencapaian potensi dirinya, walaupun dia mengalami kesulitan untuk membeli produk/merek tertentu.

Secara umum motivasi yang dominan dari seseorang untuk memenuhi kebutuhan dapat berbeda satu dengan yang lain, meskipun obyek pemenuhannya sama. Demikian pula urutan pentingnya pemenuhan kebutuhan yang dapat menimbulkan motivasi itu. Sebagai contoh motivasi dosen dan mahasiswa tentang pembelian atau pemilikan sebuah mobil. Berdasarkan tingkatan kondisional atribut mobil, jika harga sebuah mobil dapat dijadikan sebagai cerminan pemenuhan kebutuhan fisiologis, kemudahan melakukan servis - misalnya untuk perawatan dan perbaikan, sebagai kebutuhan keamanan, kapasitas penumpang untuk mencerminkan pemenuhan kebutuhan sosial, bentuk fisik mobil - misalnya tampilan eksterior atau interior, merujuk kebutuhan penghargaan, dan kecanggihan teknologi yang tersedia -misalnya untuk keamanan atau kenyamanan diri, sebagai cerminan aktualisasi diri, maka bagi seorang dosen kemungkinan kecanggihan mobil lebih penting dibandingkan bentuk fisik, kapasitas penumpang, kemudahan melakukan servis dan harga mobil, karena dengan 
rasa aman dan nyaman yang diperolehnya selama dalam perjalanan menggunakan mobil tersebut dia dapat menggunakan energi yang masih prima untuk melakukan pekerjaan lain secara optimal. Sedangkan bagi seorang mahasiswa yang kemampuan keuangannya relatif terbatas, faktor harga mungkin lebih penting dari pada kecanggihan mobil, bentuk fisik, kapasitas penumpang dan kemudahan melakukan servis.

Jika halnya demikian, ketika dosen yang bersangkutan membeli mobil, mungkin dia lebih cenderung termotivasi untuk memenuhi kebutuhan aktualisasi diri daripada kebutuhan penghargaan, sosial, keamanan, dan fisiologis. Sedangkan bagi mahasiswa tersebut cenderung mempertimbangkan kebutuhan fisiologis dibandingkan pemenuhan kebutuhan aktualisasi diri, penghargaan, sosial dan keamanan.

Adapun Freud mengemukakan pendapat tentang teori psikoanalitik kepribadian bahwa sesorang itu dalam berperilaku dipengaruhi oleh id, superego dan ego. Id adalah bagian dari kepribadian yang sifatnya primitif dan impulsif serta dipunyai seseorang sejak lahir, berisi pengharapanpengharapan yang memerlukan pemuasan secepatnya, dan aktualisasinya dapat menghasilkan tindakan bawah sadar yang dapat saling berlawanan dengan realitas yang nampak. Sedangkan superego merupakan ekspresi dari dalam diri seseorang yang berhubungan atau dikembangkan dari nilai-nilai moral masyarakat, yang aktualisasinya berupa tindakan bawah sadar yang dapat menghambat atau mengurangi kekuatan impulsif id. Adapun ego merupakan konsep pengendalian seseorang, yang berfungsi sebagai penyeimbang antara kekuatan impulsif dari id dengan konstrain budaya masyarakat dari superego (Schiffman dan Kanuk, 1994). Ketiga faktor psikoanalitik tersebut mempunyai kedudukan yang sama pentingnya antara satu dengan yang lain dalam mempengaruhi perilaku. Sebab apabila terjadi salah satu lebih dominan dibandingkan yang lain akan menimbulkan ketimpangan perilaku. Jika id dibiarkan sangat dominan, maka seseorang akan cenderung mementingkan diri sendiri. Sedangkan jika superego menguasai kepribadian seseorang, dia akan rendah diri dan takut menempuh resiko hidup. Adapun jika ego terlalu besar kendalinya terhadap id dan superego perilaku seseorang akan menjadi sulit diterima oleh orang lain.

Sebagai contoh perlunya keseimbangan ketiga hal tersebut adalah tentang suatu produk/merek baru yang relatif mahal harganya akan dibeli seseorang bukan semata-mata karena kualitasnya yang baik (ego), tetapi juga karena harga yang mahal dapat meningkatkan status dan harga diri pembelinya (id). Kemungkinan pembelian produk yang mahal itu mungkin dapat ditunda, atau bahkan dibatalkan, apabila kondisi perekonomian yang sedang buruk. Hal ini supaya yang bersangkutan tidak dianggap sombong dan menghambur-hamburkan uang, sehingga tidak menimbulkan kecemburuan sosial masyarakat lingkungannya (superego). 


\section{PENGUKURAN MOTIVASI}

Sebagai bagian dari aspek psikologis manusia, pengukuran motivasi dapat dilakukan dengan menggunakan teknik pengukuran yang disesuaikan dengan teori yang mendasari penelitian yang dilakukan. Selain melalui pendekatan secara kualitatif, motivasi konsumen juga dapat diketahui dengan pendekatan secara kuantitatif, yaitu dengan melakukan kegiatan survei melalui penyebaran angket kepada konsumen. Isi utama dari angket berupa identifikasi motivasi konsumen yang merujuk pada aspekaspek penting dari teori motivasi yang digunakan dan yang ingin diketahui oleh peneliti. Di samping itu, menurut Darrel dan kawan-kawan (1994) konsumen diminta untuk menilai produk atau jasa menurut perasaan emosional mereka atau yang dapat meningkatkan nilai mereka.

Demikian pula skala pengukuran yang dipakai. Misalnya jika penelitian menggunakan teori hirarki kebutuhan manusia dari Maslow, peneliti dapat memilih menggunakan pengungkapan pernyataan konsumen berupa data angket berskala tertentu. Hal itu diperlukan juga dalam penerapan penggunaan teori psikoanalitik kepribadian Freud. Pemilihan skala pengukuran ini sekali lagi, tergantung pada teori motivasi yang dipakai.

Pemakaian skala ordinal dalam suatu penelitian bisa bermanfaat untuk mengungkapkan pernyataan mengenai lebih daripada atau kurang daripada, tanpa menyatakan nilai lebih besar atau kurangnya; skala ordinal mempunyai urutan pernyataan, tetapi tidak mempunyai jarak dan asal mula yang unik (Cooper dan Emory, 1995). Dengan skala ordinal responden penelitian dapat menyatakan pendapat tentang urutan (ranking) pentingnya karakteristik suatu obyek penelitian (Sekaran, 1994).

Menilik karakteristik skala ordinal tersebut, maka penelitian motivasi konsumen dengan menggunakan teori hirarki kebutuhan manusia dari Maslow nampaknya akan lebih sesuai apabila menggunakan skala pengukuran ordinal. Jika halnya demikian, satu contoh penerapan hipotesis mengenai pengukuran motivasi konsumen ini dapat diberikan seperti yang terlihat dalam Gambar 2.

Gambar 2 berikut ini menunjukkan atribut yang dianggap penting oleh konsumen mengenai pilihannya untuk membeli mobil $X$. Dan pengukuran tentang pentingnya atribut-atribut yang dapat memotivasi konsumen tersebut bisa dilakukan dengan dua cara. Pada cara yang pertama (Contoh 1) nilai bobot diberikan secara langsung oleh konsumen dengan menuliskan besarnya angka bobot untuk masing-masing atribut ${ }^{2}$. Dengan melihat besarnya nilai yang diberikan tersebut dapat diketahui

\footnotetext{
2 Nilai masing-masing atribut dapat sangat bervariasi besarnya; semakin besar total bobotnya (bisa 1, 10, 100 dan lain-lain) akan semakin banyak kemungkinan variasi nilainya.
} 
dengan mudah bahwa suatu atribut dianggap lebih penting oleh konsumen dibandingkan dengan atribut yang lain untuk membeli mobil $X$. Semakin besar nilainya, semakin penting atau dominan atribut itu dalam keputusan pembelian mobil $X$.

\section{Gambar 2: Contoh Pengukuran Motivasi dengan Skala Ordinal}

Contoh 1:

Berilah bobot (angka) pada atribut produk/merek mobil sedan $X$ di bawah ini. Besarnya bobot (angka) dimaksud menunjukkan pentingnya atribut yang memotivasi Anda untuk membeli produk/merek mobil $X$ tersebut. Total bobot (angka) adalah 10.
Harga yang terjangkau Lekuk eksterior yang meliuk tegas
Penggunaan bahan bakar yang irit Kombinasi interior yang lembut
_ Kemudahan melakukan servis
Kecanggihan teknologi yang dipakai

_ Kapasitas penumpang banyak

Contoh 2:

Berilah urutan pilihan (1 sampai dengan 6) terhadap atribut produk/merek mobil $X$ di bawah ini. Urutan atribut menunjukkan pentingnya atribut tersebut dalam memotivasi Anda untuk membeli produk/merek mobil $X$.

Harga yang terjangkau

_ Penggunaan bahan bakar yang irit

_ Kemudahan melakukan servis

__ Kapasitas penumpang besar
Lekuk eksterior yang meliuk tegas Kombinasi interior yang lembut __ Kecanggihan teknologi yang dipakai

Sedangkan pada cara yang kedua (Contoh 2) konsumen diminta mengurutkan pentingnya atribut-atribut yang ada, kemudian berdasarkan urutan tersebut peneliti memberi skor tertentu. Nilai skor bersifat unipolar (satu kutub, yang sebaiknya adalah positif). Misalnya jika konsumen memilih 'harga yang terjangkau' sebagai urutan pertama, atribut 'kapasitas penumpang besar' pada urutan kedua dan setrusnya, maka atribut harga tersebut diberi skor 7, atribut kapasitas diberi skor 6 dan seterusnya.

Pengskoran unipolar seperti itu diasumsikan lebih tepat dilakukan untuk pengukuran motivasi. Asumsi ini bertolak dari wacana bahwa tidak ada sesuatu yang tidak menimbulkan motivasi, sehingga suatu atribut produk/merek yang dianggap (sama sekali) tidak penting tidak seharusnya kemudian dianggap tidak akan memotivasi konsumen, yang benar yaitu atribut tersebut kurang memotivasi konsumen. Jika hal ini betul, maka nilai skor terendah dalam katagori tersebut seharusnya bukan 0 (nol), tetapi 1 (satu).

Adapun penggunaan skala interval bermanfaat untuk memperoleh data dari pernyataan responden tentang penentuan kesamaan interval atau 
selisih; ciri-ciri skala interval pada suatu pernyataan adalah berurutan dan berjarak sama antara nilai tanggapan yang satu dengan yang lain, tetapi tidak mempunyai asal mula yang unik (Cooper dan Emory, 1995). Pengukuran dengan skala ordinal dapat diubah menjadi skala interval, apabila suatu obyek tidak lagi mempunyai urutan pentingnya karakteristik obyek itu, tetapi masing-masing karakteristik dianggap sama pentingnya (Sekaran, 1994).

Dengan dasar penjelasan tersebut, maka pengukuran motivasi konsumen yang bertolak dari teori psikoanalitik kepribadian dari Freud nampaknya cenderung lebih cocok menggunakan skala pengukuran interval, karena -berdasarkan uraian teori Freud sebelumnya- santara karakteristik-karakteristik pada konsep id, superego dan ego adalah sama pentingnya atau setara. Dengan asumsi itu dapat dibuat aplikasi pengukuran motivasi konsumen untuk membeli mobil $X$, yang hipotesisnya bisa dicontohkan seperti yang nampak pada Gambar 3.

\section{Gambar 3: Contoh Pengukuran Motivasi dengan Skala Interval}

Berilah tanda silang $[X]$ di bagian kolom tanggapan penting-tidak penting

untuk masing-masing pernyataan yang ada.

Saya membeli mobil $X$ karena:

Harga yang terjangkau

Penggunaan bahan bakar yang irit

Kemudahan melakukan servis

Kapasitas penumpang besar

Lekuk eksterior yang meliuk tegas

Kombinasi interior yang lembut

Kecanggihan teknologi yang dipakai

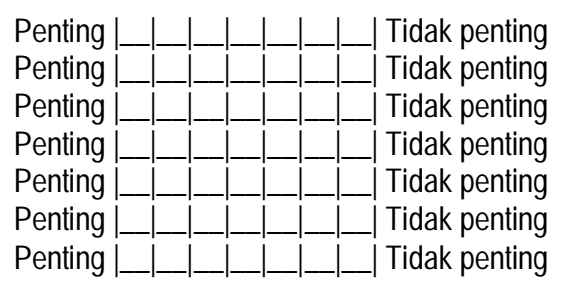

Pada Gambar 3 tersebut pernyataan tentang atribut produk/merek mobil X dikemukakan lebih rinci dari pada contoh pada Gambar 2, karena tuntutan pengukuran penelitian dengan skala interval serta aplikasi pengungkapan teori Freud memang demikian. Sedangkan tanggapan pernyataan dari konsumen dinilai secara unipolar dengan skor 7 (sangat penting) ke skor 1 (tidak penting), dengan penjelasan (alasan) sifat pengskoran unipolar seperti yang telah dikemukakan pada Contoh 2 dari Gambar $2^{3}$. Dengan cara pengukuran ini skor pada masing-masing atribut

\footnotetext{
3 Pada penerapan yang lain dapat juga dipergunakan penilaian (skor) tanggapan yang berjajar 5 ruas, 10 ruas dan sebagainya.
} 
kemungkinan bisa mempunyai nilai yang sama (7 semua, 1 semua, dan sebagainya) atau bervariasi.

Di samping itu, agar informasi yang diperoleh dapat lebih tajam, peneliti mungkin bisa memberi bagian tersendiri dari angket penelitian supaya konsumen dapat memberi alasan khusus mengenai pilihan pentingtidak pentingnya atribut produk/merek itu. Pernyataan alasan konsumen tersebut diharapkan dapat mengungkap lebih banyak motivasi bawah sadar konsumen (dari id dan superego) untuk membeli produk/merek itu. Jika langkah ini dilakukan, peneliti mungkin dapat memperoleh informasi seperti yang didapat oleh Ernest Dichter (Wells dan Prensky, 1996), seperti yang ditunjukkan pada Gambar 4.

\begin{tabular}{|c|c|c|}
\hline \multicolumn{3}{|c|}{$\begin{array}{l}\text { Gambar 4: Contoh identifikasi kebutuhan dan produk oleh Dichter } \\
\text { (Wells dan Prensky, 1996) }\end{array}$} \\
\hline Produk & Kepentingan utama & Kepentingan dari bawah sadar \\
\hline$\overline{M a k a n a n}$ yang dibungkus & Melindungi makanan & Perhatian terhadap keluarga \\
\hline Perkakas tukang & Perbaikan rumah & Menunjukkan ketrampilan dan kemampuan \\
\hline Eskrim & Nutrisi, selera & $\begin{array}{l}\text { Cinta dan perasaan yang berhubungan dengan } \\
\text { memori masa kanak-kanak }\end{array}$ \\
\hline Topi & Kaamanan, keramahan & Ekspresi diri dan kepribadian \\
\hline Deodoran & $\begin{array}{l}\text { Mengurangi bau dan } \\
\text { kebasahan }\end{array}$ & Penghargaan diri dan kepentingan sosial \\
\hline
\end{tabular}

Dua bentuk pengukuran motivasi dengan skala ordinal dan interval seperti yang telah dikemukakan pada ilustrasi di atas sebenarnya hanya sekedar contoh penerapan dari berbagai teori motivasi yang mendasari penelitian motivasi. Teknik pengukuran skala ordinal yang dipergunakan untuk mengetahui motivasi konsumen melalui pendekatan teori Maslow, pada dasarnya dapat juga dipakai pada penelitian yang menggunakan dasar teori hirarki kebutuhan manusia yang lain, seperti teori kepuasan dari Herzberg (Kotler, 1994), teori psychologis dari McGuire's (Hawkins, Best, dan Coney, 1992), atau teori kebutuhan belajar dari McClelland (Mowen dan Minor, 1998). Demikian pula teknik pengukuran berskala interval pada penelitian motivasi dengan pendekatan teori Freud, dapat juga dipakai untuk penerapan penelitian pada teori motivasi pembelian dari Ernest Dichter serta teori compliant, aggressives, detached (CAD) dari Karen Horney (Wells dan Prensky, 1996)4.

\footnotetext{
${ }^{4}$ Cara kedua ini juga dilakukan misalnya oleh Wetter, Brandon dan Ba1ker (1992), Zweigenhaft at.al
} (1996) dan Chantal, Vallerand dan Vallieres (1995). 


\section{ANALISIS DATA}

Bentuk pengukuran motivasi dengan menggunakan angket seperti yang telah dicontohkan di atas tidak hanya diberikan kepada satu orang saja, tetapi dibutuhkan banyak orang (sampel atau populasi) agar dapat diperoleh gambaran kecenderungan motivasi konsumen untuk membeli produk/merek tertentu. Karena itu diperlukan teknik analisis statistika, baik yang diskriptif maupun yang inferensial, sehingga kesimpulan yang diambil dapat lebih informatif (berdaya guna) dan dapat dipertanggungjawabkan. Beberapa teknik analisis statistika yang dapat membantu adalah sebagai berikut:

a. Untuk memperoleh skor nilai representatif dari pernyataan motivasi konsumen dapat dipergunakan alat analisis diskriptif rata-rata hitung. Melalui alat analisis ini dapat diketahui sumbangan rata-rata masingmasing atribut terhadap total rata-rata masing-masing faktor, sehingga dapat ditetapkan kecenderungan atribut yang dominan memotivasi konsumen. Menurut Hadi (1989) dalam prakteknya sarjana-sarjana sosial banyak menggunakan rata-rata hitung ini, baik untuk data yang berskala ordinal maupun interval ${ }^{5}$.

b. Untuk menguji adanya perbedaan frekuensi (proporsi) data amatan yang diperoleh dengan yang diharapkan dari masing-masing atribut pada suatu produk/merek tertentu dapat dipergunakan alat statistika: uji beda frekuensi kai kuadrat 1-jalur dan uji beda proporsi kelompok tunggal Kolmogorov-Smirnov atau Mann-Whitney U. Melalui analisis ini dapat ditentukan ada tidaknya perbedaan mengenai harapan konsumen dengan yang dapat disediakan produsen (penjual) tentang suatu aribut produk/merek, sehingga dapat dibuat perlakuan khusus bagi atribut tersebut untuk [sedapat mungkin] memenuhi harapan konsumen.

c. Untuk menguji adanya perbedaan skor nilai dari pernyataan konsumen untuk masing-masing atribut dari serangkaian produk/merek perusahaan dan pesaingnya dapat dipergunakan alat analisis: uji beda amatan ulangan dari Friedman dan analisis varian (anava) amatan ulangan 1-faktor. Dari analisis ini dapat ditentukan bahwa masing-masing produk/merek yang diteliti benar-benar disertai atau mempunyai keunikan (keunggulan) tertentu atau tidak.

d. Untuk menguji adanya hubungan atau perbedaan skor nilai dari pernyataan konsumen pada masing-masing atribut dari suatu produk/merek, dan pernyataan itu dipengaruhi pula oleh karakteristik/latar

\footnotetext{
5 Dalam banyak literatur metodologi penelitian, sangat dianjurkan data penelitian berskala ordinal menggunakan alat analisis yang tidak didasarkan pada satuan-satuan yang berjarak sama, seperti median dan mode (modus).
} 
belakang konsumen (usia, pendidikan, penghasilan, dan sebagainya) dapat dipergunakan alat analisis: uji beda jenjang antar kelompok Kruskal-Wallis dan anava 1-jalur. Dengan analisis ini dapat diketahui ada-tidaknya perbedaan penilaian konsumen tentang atribut tertentu dari suatu produk/merek menurut variasi karakteristik konsumen tertentu.

e. Untuk menguji adanya hubungan atau perbedaan skor nilai dari pernyataan konsumen pada masing-masing atribut dari serangkaian produk/merek, serta dipengaruhi pula oleh karakteristik/latar belakang konsumen (usia, pendidikan, penghasilan, dan sebagainya) bisa dipergunakan alat analisis: anava 1-jalur mixed amatan ulangan 1faktor, sehingga dapat diperoleh ada tidaknya perbedaaan penilaian konsumen tentang atribut tertentu dari serangkaian produk/merek yang diteliti berdasarkan pada variasi karakteristik konsumen tertentu.

Pada wacana statistika, umumnya alat analisis yang diformat untuk skala pengukuran tertentu juga dapat dipergunakan untuk skala yang lebih tinggi tingkatannya. Karena itu alat analisis statistika inferensial (butir $\mathrm{b}-\mathrm{e}$ ) yang direkomendasikan di atas -umumnya untuk skala pengukuran ordinal, juga dapat dipergunakan untuk data yang berskala interval.

\section{IMPLIKASI DALAM PEMASARAN}

Manfaat yang dapat diperoleh pemasar ketika menggunakan salah satu alternatif dari dua teori beserta prosedur penelitian berikutnya tentu saja dapat berbeda. Penelitian yang menggunakan skala interval -sesuai dengan karakteristik pengukuran datanya yang lebih tinggi tingkatannya, dapat menghasilkan implikasi pemasaran yang lebih tajam atau rinci dibandingkan yang dengan berskala ordinal. Dalam contoh kasus di muka, skala interval tidak hanya bisa mengungkapkan pentingnya atribut itu, tetapi juga nilai pentingnya masing-masing atribut tersebut. Tetapi secara umum kedua cara itu dapat menimbulkan manfaat sebagai berikut:

Pertama, dalam strategi promosi. Pemasar dapat memperoleh data yang jelas tentang kedudukan atribut yang dianggap penting oleh konsumen, sehingga dapat mengfokuskan keunggulan atribut tersebut pada program dan kegiatan promosi yang lebih efektif. Misalnya berupa tampilan iklan atau promosi penjualan yang dapat menggugah perasaan konsumen, atau membekali pengetahuan kepada armada penjualan personal yang dapat membantu mereka agar dapat lebih lancar dan familier dalam menjelaskan karakteristik produk/mereknya kepada konsumen.

Kedua, perbaikan produk. Pemasar dapat segera memperbaiki tampilan atau isi produk/merek sebagai bentuk kepeduliannya terhadap 
keinginan dan permintaan konsumen, khususnya pada atribut yang dianggap tidak penting atau kurang memotivasi konsumen untuk membeli. Selanjutnya bersama-sama dengan atribut yang dianggap penting dan secara relatif telah ada pada produk/merek tersebut dapat diberitakan secara luas kepada konsumen untuk menambah kesan baik bahwa perusahaan sudah melakukan perbaikan produk/merek yang sesuai dengan keinginan dan permintaan konsumen tersebut.

Ketiga, pemilihan pasar sasaran. Apabila tanggapan pernyataan motivasi dikaitkan pula dengan data geografi (misalnya: bagian wilayah dan luas daerah), demografi (misalnya: usia, pendapatan dan pendidikan), dan sosial budaya (misalnya: agama dan kelas sosial) konsumen, maka hasil penelitian dapat digunakan sebagai dasar untuk memilih atau mengembangkan pasar sasaran yang tepat dan menguntungkan pemasar, karena program dan kegiatan pemasaran dapat terfokus sesuai dengan karakteristik konsumennya.

Keempat, prediksi penjualan. Apabila penelitian juga melibatkan merek pesaing yang setara, atau bahkan variasi produk pesaing yang sedikit berbeda dengan merek perusahaan, maka pemasar dapat memperoleh data tentang keunggulan dan kelemahan produk/mereknya di tengah industrinya, sehingga dapat ditetapkan strategi pemasaran yang tepat dalam menghadapi persaingan. Di samping data tersebut dapat pula berguna untuk prediksi pangsa pasar industri, sehingga dapat dilakukan rencana penjualan lebih tepat dan bisa menghasilkan manfaat yang terbaik bagi perusahaan.

PENUTUP

Seperti halnya dalam kegiatan penelitian yang lain, pemilihan pendekatan teori motivasi dan skala pengukuran yang dipergunakan dalam penelitian motivasi pada dasarnya harus disesuaikan dengan masalah dan tujuan penelitian yang ingin dipecahkan atau dicapai. Dengan kata lain, pendekatan teori dan skala pengukuran yang satu tidak bisa menggantikan pendekatan teori dan skala pengukuran yang lain.

Dalam rangka memperoleh data yang informatif dan dapat dipertanggungjawabkan, maka peneliti tidak boleh 'memaksa' konsumen atau responden untuk menerima begitu saja berbagai atribut produk/merek yang diajukan peneliti. Hal itu karena peneliti itu sendiri belum tentu dalam posisi sebagai konsumen. Kalau pun sebagai konsumen, dia hanya satu dari sekian banyak konsumen produk/merek bersangkutan, sehingga atribut yang dianggap penting oleh peneliti belum tentu representatif sebagai pilihan dari konsumen lain. Untuk mengurangi kelemahan ini, maka peneliti perlu melakukan penelitian pendahuluan kepada sebagian 
konsumen untuk menentukan atribut penting dari produk/merek tersebut. Atribut penting yang dipilih konsumen tersebut kemudian dijadikan dasar dalam penyusunan pernyataan dalam pengukuran sikap, seperti yang telah dicontohkan di muka (Albari, 1999).

Peneliti juga perlu memanfaatkan teknologi program pengolahan data, misalnya SPSS atau SAS, utamanya jika digunakan populasi atau sample besar. Dengan cara komputerisasi ini tenaga, waktu dan biaya yang dihemat akan sangat berarti, di samping akurasi perhitungan dapat diandalkan.

\section{DAFTAR PUSTAKA}

Albari (1996), "Motivasi Menjadi Anggota Koperasi pada Koperasi Pegawai Negeri di Yogyakarta", Jurnal Siasat Bisnis, 1 (1): 62-71.

, (1999), "Sikap Konsumen: Pemilihan Model dan Penelitiannya", Jurnal Siasat Bisnis, 4 (7): 51-64.

Alvin, A.A. (1993), "The Future Challenge to Market Research", Marketing Research, 5 (2): 12-19.

Assael, H. (1992), Consumer Behavior and Marketing Action, $4^{\text {th }}$ ed., Boston: PWS-KENT Publishing Company.

Bleckwell, R.D., P.W. Miniard and J.F. Engel (2001), Consumer behavior, 9th ed., Orlando: Hourcourt College Publishers.

Blythe, J. (1997), The Essence of Consumer Behavior, London: Prentice Hall.

Bowerman, B.L., R.T. O'Connell and L.L. Hand (2001), Business Statistics in Practice, $2^{\text {th }}$ ed., New York: The McGrow-Hill Companies, Inc.

Burton, F.G. at al. (1993), "An Application of Expectancy Theory for Assessing User Motivation to Utilize an Expert System", Journal of Management Information System, 9 (3): 183-198.

Chantal, Y., R.J. Vallerand and E.F. Vallieres (1995), "Motivation and Gambling Involvement", The Journal of Social Psychology, 135 (6): 755-763.

Churchill Jr., G.A. ((1999), Marketing Research: Methodological Foundations, $6^{\text {th }}$ ed., Orlando: The Dryden Press.

Cooper, D.R. and C.W. Emory (1995), Business Research Methods, $5^{\text {th }}$ ed., Illionis: Richard D. Irwin, Inc.

Darrel, E. et al. (1994), "Typical Definition of 'Satisfaction' is Too Limited", Marceting News, 28 (1): 6-8. 
East, R. (1997), Consumer Behaviour: Advances and Applications in Marketing, London: Prentice Hall.

Fishbein, M. and I. Ajzen (1975), Belief, Attitude, Intention, and Behavior: An Introduction to Theory and Research, Massachusetts: AddisonWesley Publishing Company, Inc.

Foxall, G., R. Goldsmith and S. Brown (1998), Consumer Psychology for Marketing, $2^{\text {th }}$ ed., London: International Thomson Business Press.

Gordon, W. (1995), "Researching Channels", Marketing Research, 7 (3): $42-45$.

Hadi, S., (1989), Metodologi Researh, Jilid II, Yogyakarta: Andi Offset

Hadi, S., Seno Pamardiyanto, dan Y.P. Kuncoro S. (1996), Buku Manual SPS: Paket MIDI, Yogyakarta: Universitas Gadjah Mada.

Hawkins, D.I., R.J. Best, and K.A. Coney (1992), Consumer Behavior: Implications for Marketing Strategy, $5^{\text {th }}$ ed., Illionis: Richard D. Irwin, Inc.

Kardes, F.R. (1999), Consumer Behavior and Managerial Decision Making, Massachussetts: Addison-Wesley Educational Publishers, Inc.

Kotler, P. (1994), Marketing Management: Analysing, Planning, Implementation, and Control, $8^{\text {th }}$ ed., New Jersey: Prentice Hall International, Inc.

Lilien, G.L., P. Kotler, and K.S. Moorthy (1992), Marketing Models, New Jersey: Prentice Hall, Englewood Cliffs.

Loudon, D.L. and A.J. Della Bitta (1993), Consumer Behavior: Concept and applications, 4th ed., New York: McGraw-Hill, Inc.

Malhotra, N.K. (1999), Marketing Research: An Apllied Orientation, $3^{\text {th }}$ ed., New Jersey: Prentice Hall International, Inc.

Moven, J.C. (1987), Consumer Behavior, New York: Macmillan Publishing Co.

Moven, J.C. and M. Minor (1998), Consumer Behavior, $5^{\text {th }}$ ed., New Jersey: Prentice Hall International, Inc.

Newbolt, P. (1995), Statistics for Business \& Economics, $4^{\text {th }}$ ed., New Jersey: Prentice-Hall International, Inc.

Peter, J.P. and J.C. Olson (1996), Consumer Behavior and Marketing Strategy, $4^{\text {th }}$ ed., Chicago: Richard D. Irwin, Inc.

Schiffman, L.G. and L.L. Kanuk (1997), Consumer Behavior, 6th ed., New Jersey: Prentice Hall International, Inc. 
Sekaran, U. (1994), Research Methods for Business, $2^{\text {th }}$ ed., Toronto: John Wiley \& Sons, Inc.

Solomon, M.R. (1999), Consumer Behavior, $4^{\text {th }}$ ed., New Jersey: Prentice Hall, Inc.

Thomas, J.W. (1998), "Motivational Research: Explaning Why Consumers Behave the Way They Do", Direct Marketing, 60 (12): 54-57.

Welkowitz,J., R.B. Ewen and J. Cohen (2000), Introductory Statistics for the Behavioral Sciences, $5^{\text {th }}$ ed., Orlando: Harcourt Brace \& Company.

Wells, W.D. and D. Prensky (1996), Consumer Behavior, New York: John Wiley \& Sons, Inc.

Wetter, D.W., T.H. Brandon and T.B. Baker (1992), "The Relation of Affective Processing Measures and Smoking Motivation Indices among College-Age Smokes", Journal of Advertising and Behavior, Vol 14: 169-193.

Zikmund, W.G. (1997), Business Research Methods, $5^{\text {th }}$ ed., Orlando: The Dryden Press.

Zweigenhaft, R.L. at al. (1996), "The Motivations and Effectiveness of Hospital Volunteers", The Journal of Social Psychology, 136 (1): 25-34. 